\title{
WhatsApp-based intervention for promoting physical activity among female college students, Saudi Arabia: a randomized controlled trial
}

Amal Alshahrani, ${ }^{1}$ Aesha Siddiqui, ${ }^{2}$ Shamsun Khalil, ${ }^{2}$ Shehata Farag, ${ }^{2,3}$ Najim Alshahrani, ${ }^{4}$ Abdullah Alsabaani ${ }^{2}$ and Hassan Korairi ${ }^{5}$

${ }^{1}$ Department of Public Health, General Directorate of Health Affairs in Aseer Region, Ministry of Health, Abha, Saudi Arabia (Correspondence to: A. Alshahrani: amal.jrais@gmail.com). ${ }^{2}$ Department of Family and Community Medicine, King Khalid University, Abha, Saudi Arabia. 3Biostatistics Department, High Institute of Public Health, Alexandria University, Alexandria, Egypt . ${ }^{4}$ Department of Family and Community Medicine, Faculty of Medicine, University of Jeddah, Jeddah, Saudi Arabia. ${ }^{5}$ Department of Preventive Medicine, Armed Forced Hospitals in Southern Region, Khamis Mushayt, Saudi Arabia.

\begin{abstract}
Background: Social media are increasingly being used by young adults worldwide. The question is whether they can be successfully incorporated into health programmes to promote physical activity.

Aims: To measure the effect of a WhatsApp-based intervention for promoting physical activity among female college students in Abha, Saudi Arabia.

Methods: This randomized controlled trial from November 2019 to January 2020 included 110 students. The intervention group received a brief orientation on exercise and up to 4 physical activity promotion messages per week via WhatsApp for 10 weeks. The messages were obtained from the websites of the US Centers for Disease Control and World Health Organization (WHO). Physical activity was assessed at baseline and at 10-weeks' follow-up using the WHO Global Physical Activity Questionnaire.

Results: The 2 groups were similar in sociodemographic and baseline physical activity levels. Postintervention data analysis revealed significant improvement in the proportion of participants with moderate-intensity physical activity in the work and recreation domains. Compared with the control group, mean metabolic equivalents/week of the intervention group improved significantly. The mean difference in total physical activity before and after intervention was significant in all domains and in all categories of activity. The proportion of participants who met the WHO criteria for minimum physical activity per week increased from $69.8 \%$ to $90.5 \%$ after intervention.

Conclusion: Social-network-based interventions improve physical activity and may be incorporated into youth-targeted health programmes.

Keywords: health promotion, mobile applications, physical activity, social media, WhatsApp

Citation: Alshahrani A; Siddiqui A; Khalil S; Farag S; Alshahrani N; Alsabbani A; et al. WhatsApp-based intervention for promoting physical activity among female college students, Saudi Arabia: a randomized controlled trial. East Mediterr Health J. 2021;27(8):782-789. https://doi.org/10.26719/emhj.21.012

Received: 13/08/20; accepted 02/12/20

Copyright (C) World Health Organization (WHO) 2021. Open Access. Some rights reserved. This work is available under the CC BY-NC-SA 3.0 IGO license (https://creativecommons.org/licenses/by-nc-sa/3.o/igo)
\end{abstract}

\section{Introduction}

Physical activity is a well-established element of the public health agenda (1). A recent World Health Organization (WHO) report states that around $23 \%$ of adults aged $\geq$ 18 years are not physically active enough (2). Absence of physical activity is among the main risk factors for noncommunicable diseases and overall mortality $(2,3)$. It is estimated that inactivity is globally responsible for $9 \%$ of premature mortality, or > 5.3 million deaths annually (3). Physical activity is recognized to significantly decrease cardiovascular risks, improve lipid profile, control type 2 diabetes, prevent some types of cancer, raise bone density, improve psychological health and reduce overall mortality (4).

During the past few decades, Saudi Arabia has witnessed enormous economic growth and prosperity, accompanied by a technological transformation that has led to major negative changes in lifestyle. The transition to university frequently occurs among students aged
18-24 years. This is a critical time for substantial and rapid weight gain as a result of poor dietary habits. Healthy behaviour, such as physical activity, is often compromised among college students. As these years play an essential role in the development of health behaviour that continues into adulthood, it is important to develop programmes to encourage healthy weightrelated behaviour for university students (5).

Although limited, studies have used social media and self-monitoring apps to improve weight-related behaviours and have found positive results in college students and women. Miller et al. conducted a survey on the effectiveness of a health promotion smartphone app for college students. The students believed that the app was beneficial and helpful in that it promoted healthy behaviour and raised awareness (6). A study in Saudi Arabia reported that social media are effective in reducing body weight among college students and are a promising way of increasing physical activity (7). Fukuoka et al. 
investigated the use of a mobile-phone-based intervention to improve physical activity in sedentary women. They concluded that the intervention motivated inactive women to improve their physical activity (8). Another study reported that mobile-phone-based interventions are cost-effective for promotion of physical activity as compared with face-to-face interventions (9).

Saudi Arabia has one of the highest mobile penetration rates in the world, at a level of $72.8 \%$. Social networking applications such as WhatsApp, Facebook and Twitter have become popular means of communication, especially among young adults (10). In Saudi Arabia, WhatsApp is one of the most popular mobile social networking platforms and is used by 56$72 \%$ of the population (11). WhatsApp has been widely used in health care (12). The aim of this study was to test the effectiveness of a WhatsApp-based physical activity promotion intervention to improve physical activity levels among Saudi female college students.

\section{Methods}

\section{Study design}

The current study had a pretest/post-test randomized controlled open label experimental design. The study setting was faculties of medicine, dentistry, pharmacy, nursing, applied medical science, and information systems.

\section{Study population and sampling technique}

All female students at King Khalid University, aged 1828 years, who owned a smartphone with internet access and WhatsApp and were willing to complete all study requirements were invited to participate. Those who could not exercise [physical disability, morbid obesity (body mass index $\left.>45 \mathrm{~kg} / \mathrm{m}^{2}\right)$ ] or were pregnant were excluded. A total of 110 participants (55 per group) was required to estimate expected difference in adherence to physical activity ( $17 \%$ vs $4 \%)$ for the intervention and control groups, respectively (13), with $10 \%$ more to avoid attrition effects. This difference provided an effective size for intervention of 0.76 (large) at $95 \%$ confidence level with study power of $80 \%$.

A total of 120 participants were assessed for eligibility by convenience sampling. The study objectives and expected benefits were explained and 110 agreed to participate. After obtaining participants' consent and performing baseline assessment of their characteristics and study measures, participants were randomly allocated using computer-generated random numbers by Microsoft Excel and 55 participants were assigned to the intervention and control groups.

The WhatsApp free messenger application was used as the intervention tool. The participants used their own phones and had experience using the WhatsApp mobile social application. WhatsApp groups were formed within each study group. The control participants had the alternative group only for communications between them and the main investigator; they kept their usual activity for 10 weeks. The intervention participants had a WhatsApp group that received a 15-minute orientation on exercise, and the benefits of keeping a healthy life pattern. They also received 3 or 4 health-promotional (physical activity) messages from the literature review recommendation per week via WhatsApp for 10 weeks. Average physical activity was assessed in all participants at baseline and at 10-weeks' follow-up using the World Health Organization (WHO) Global Physical Activity Questionnaire (GPAQ) (14). After the study ended and the utility of the programme was established, the same material given to the intervention group was sent to the control group. Two participants withdrew from the intervention group leaving 53 participants, and 5 left the control group, leaving 50 participants.

\section{Outcome measures}

Outcome measures were to: compare baseline physical activity in the intervention and control groups according to three domains; compare baseline and postintervention physical activity in the intervention and control groups; and compare postintervention physical activity in the intervention and control groups.

\section{Statistical analysis}

After data were extracted, they were coded and entered into IBM SPSS version 23 statistical software. Data were cleaned and analysed according to the guide for GPAQ (15). There were 3 main domains of physical activity: 1, activity at work; 2, travel to and from places; and 3, recreational activities. Domains 1 and 3 had 2 subdomains of moderate and vigorous physical activity, giving a total of 5 groups of physical activity.

Other calculations for physical activity were done. (1) Metabolic equivalents (METs): the ratio of a person's working metabolic rate relative to the resting metabolic rate. One MET is defined as the energy cost of sitting quietly, and is equivalent to a caloric consumption of 1 kcal/kg/hour. (2) Total physical activity: MET (minutes/ week = sum of the total MET minutes of activity calculated for each setting).

Equation: total physical activity MET minutes/week $=\left(\mathrm{P}_{2}^{\prime} \mathrm{P}_{3}{ }^{\prime} 8\right)+\left(\mathrm{P}_{5}{ }^{\prime} \mathrm{P} 66^{\prime} 4\right)+\left(\mathrm{P}^{\prime} \mathrm{P}_{9}^{\prime} 4\right)+\left(\mathrm{P}_{11}^{\prime} \mathrm{P} 12{ }^{\prime} 8\right)+$ (P14' $\left.15^{\prime} 4\right)$

Sum of all activity per week divided by 7 to obtain average daily minutes if activity $=\left(\mathrm{P}_{2}{ }^{\prime} \mathrm{P}_{3}\right)+\left(\mathrm{P}_{5}{ }^{\prime} \mathrm{P} 6\right)+$ $\left(\mathrm{P}^{\prime}{ }^{\prime} \mathrm{P} 9\right)+\left(\mathrm{P}_{11}{ }^{\prime} \mathrm{P} 12\right)+\left(\mathrm{P}_{14}{ }^{\prime} \mathrm{P} 15\right) / 7$

Data were then analysed using descriptive statistics - frequency and percentage distribution for categorical data, and mean and standard deviation for continuous data. A paired $t$ test was conducted to compare changes in physical activity before and after the intervention within each group. An independent $t$ test was conducted to compare the physical activity between the intervention and control groups. McNemar's $\chi^{2}$ test was used to study the percentage difference in activity before and after intervention. To study the association between sociodemographic factors and physical activity, a $\mathrm{c}^{2}$ test 
was performed. All statistical analysis was done using 2-tailed tests and a error of 0.05. P $\leq 0.05$ was considered to be statistically significant.

\section{Results}

Table 1 presents information on the basic sociodemographic characteristics of 103 participants. In the intervention group, $71.7 \%$ were aged $\geq 20$ years, compared with $68 \%$ in the control group. More than $90 \%$ were single in both groups. Three quarters of the students in both groups reported a family monthly income of $>10000$ SR. None of the sociodemographic factors were significantly different between the intervention and control groups.

A significant difference was observed in the preand post-MET when the groups were compared after intervention [4053.21 (3601.33) and 2010.8 (2277.2); $P<$ $0.001]$ and when the intervention group was compared before and after intervention [2492.45 (2291.45) and 4053.21 (3601.33); $P<0.001$ ] (Table 2). In the control group there was a nonsignificant decrease in the MET minutes per week. Before intervention, MET minutes per week did not differ significantly between the groups. The difference in analysis of difference revealed a value of 1925.9 [95\% confidence interval $(\mathrm{CI})=1101-2750]$.

In the intervention group, 37 participants (69.8\%) met the criteria before intervention, which increased significantly to 48 participants (90.5\%) after intervention, a percentage difference of $20.7 \%$ (95\% CI $=3.78-37.6 \%$ ) (Table 3). Within the control group, before and after intervention revealed a difference of $-6.0 \%$. The difference in analysis of difference showed $26.7 \%$ (95\% CI $=18.1-$ $35.3 \%)$. In the postintervention phase, in the control group, $35(70 \%)$ participants met the WHO criteria, compared with $90.5 \%$ in the intervention group, a percentage difference of $20.5 \%$ (95\% CI $=3.60-37.4 \%)$.

The mean difference in total physical activity before and after intervention was significant in all domains and all categories of activity (Table 4). The mean difference in work-related moderate physical activity was 168.67 minutes $(P<0.001)$. The mean difference in travel-re-

\begin{tabular}{|c|c|c|c|c|c|}
\hline \multirow[t]{3}{*}{ Personal data } & \multicolumn{4}{|c|}{ Group } & \multirow[t]{3}{*}{$\mathbf{P}$} \\
\hline & \multicolumn{2}{|c|}{ Intervention } & \multicolumn{2}{|c|}{ Control } & \\
\hline & No. & $\%$ & No. & $\%$ & \\
\hline \multicolumn{6}{|l|}{ Age, year } \\
\hline$<20$ & 15 & $28.3 \%$ & 16 & $32.0 \%$ & \multirow[t]{2}{*}{0.683} \\
\hline$\geq 20$ & 38 & $71.7 \%$ & 34 & $68.0 \%$ & \\
\hline \multicolumn{6}{|l|}{ Marital status ${ }^{a}$} \\
\hline Single & 48 & $90.6 \%$ & 46 & $92.0 \%$ & \multirow[t]{2}{*}{0.797} \\
\hline Married & 5 & $9.4 \%$ & 4 & $8.0 \%$ & \\
\hline \multicolumn{6}{|l|}{ Specialty } \\
\hline Health & 21 & $39.6 \%$ & 22 & $44.0 \%$ & \multirow[t]{3}{*}{0.884} \\
\hline Computers & 18 & $34.0 \%$ & 15 & $30.0 \%$ & \\
\hline Medicine & 14 & $26.4 \%$ & 13 & $26.0 \%$ & \\
\hline \multicolumn{6}{|l|}{ Father's education } \\
\hline Up to high school & 16 & $30.2 \%$ & 16 & $32.0 \%$ & \multirow[t]{2}{*}{0.843} \\
\hline University and postgraduate & 37 & $69.8 \%$ & 34 & $68.0 \%$ & \\
\hline \multicolumn{6}{|l|}{ Mother's education } \\
\hline Up to high school & 31 & $58.5 \%$ & 29 & $58.0 \%$ & \multirow[t]{2}{*}{0.960} \\
\hline University and postgraduate & 22 & $41.5 \%$ & 21 & $42.0 \%$ & \\
\hline \multicolumn{6}{|l|}{ Father's work } \\
\hline Working & 40 & $75.5 \%$ & 38 & $76.0 \%$ & \multirow[t]{2}{*}{0.950} \\
\hline Retired/not working & 13 & $24.5 \%$ & 12 & $24.0 \%$ & \\
\hline \multicolumn{6}{|l|}{ Mother's work } \\
\hline Housewife & 32 & $60.4 \%$ & 29 & $58.0 \%$ & \multirow[t]{2}{*}{0.806} \\
\hline Working & 21 & $39.6 \%$ & 21 & $42.0 \%$ & \\
\hline \multicolumn{6}{|l|}{ Monthly income $e^{a}$} \\
\hline$<2000 \mathrm{SR}$ & 1 & $1.9 \%$ & 1 & $2.0 \%$ & \multirow[t]{4}{*}{0.999} \\
\hline $2000-5000 S R$ & 3 & $5.7 \%$ & 3 & $6.0 \%$ & \\
\hline 5000-10 000 SR & 9 & $17.0 \%$ & 9 & $18.0 \%$ & \\
\hline$>10000 \mathrm{SR}$ & 40 & $75.5 \%$ & 37 & $74.0 \%$ & \\
\hline
\end{tabular}

${ }^{a}$ Exact probability test for marital status and monthly income. 


\begin{tabular}{|c|c|c|c|c|}
\hline Group & $\begin{array}{l}\text { MET per week } \\
\text { Mean (SD) }\end{array}$ & $\begin{array}{c}\text { Mean } \\
\text { difference }\end{array}$ & SE & $\begin{array}{l}\text { Difference in difference } \\
(95 \% \mathrm{CI})\end{array}$ \\
\hline \multicolumn{5}{|c|}{ Within intervention group $(n=53)$} \\
\hline Preintervention phase & $2492.45(2291.45)$ & \multirow[t]{2}{*}{1560.75} & \multirow[t]{2}{*}{362.4} & \\
\hline Postintervention phase & $4053.21(3601.33)$ & & & $1925.9(1101-2750.9)$ \\
\hline \multicolumn{5}{|l|}{ Within control group $(n=50)$} \\
\hline Preintervention phase & $2376.0(2275)$ & \multirow[t]{2}{*}{-365.2} & \multirow[t]{2}{*}{201.4} & \\
\hline Postintervention phase & $2010.8(2277.2)$ & & & \\
\hline
\end{tabular}

$\mathrm{CI}=$ confidence interval; $\mathrm{MET}=$ metabolic equivalents; $S D=$ standard deviation; $S E=$ standard error .

lated total physical activity per week was 62.73 minutes $(P<0.001)$.The mean difference in moderate recreational activity was 58.60 minutes $(P=0.006)$. The mean difference in total physical activity per day was 48.01 minutes $(P<0.001)$.

The mean MET per minute differed significantly before and after intervention in the domain of moderate work-related activity $(P=0.006)$, travel-related activity $(P=0.007)$, and moderate recreational activity $(P=0.049)$ (Table 5). The total MET per week also showed a significant improvement with a mean difference of 625.8 MET/min $(P=0.008)$.

\section{Discussion}

The results of the current study revealed that there were no significant differences between the intervention and control groups regarding sociodemographic characteristics and baseline physical activity in any of the domains in female college students in Saudi Arabia. A comparison of total physical activity in all 3 domains in the preintervention phase did not show any significant difference. The average daily physical activity also did not show any difference between the groups. Analysis of the share of physical activity by domain revealed that recreational activity was the most common, with about half of the share of all activity. These findings are similar to earlier reports $(16,17)$. One in 10 of our participants did not report any physical activity before the intervention.

The effect of the intervention was demonstrated by a change in the proportion of students before and after the intervention who reported physical activity in all domains. There was an increase in the proportion of students reporting physical activity in all 3 domains and all categories of physical activity. It is interesting to note that out of 6 inactive participants in the intervention group, 4 reported activities in postintervention analysis, while 1 in 5 in the control group showed the shift. This is an important finding that highlights the effectiveness of the WhatsApp-based physical activity intervention. The increase in the proportion of students reporting moderate activity in the domain of work-related activity was significant, and it was the same for recreationrelated activity. These findings suggest that for young women, improvement in levels of moderate activity is achievable. Considering the social limitations in the young female population of Saudi Arabia, it is often impractical and challenging to have live interactive sessions and community exercise programmes. Thus, social media can play an essential role in reaching individually to this group. Considering the specific degrees of activity in various domains, the proportion of participants who met the WHO criteria increased in the intervention group from $69.8 \%$ to $90 \%$. These findings accord with other studies from different regions of the world. A study from the United States of America on perceptions and experiences of women participating in a digital-technology-based physical activity intervention reported that a greater proportion of participants in the intervention group, compared with the control group, engaged in brisk walking (18). A study of American university students also reported similar results to the current study, concluding that web-based physical activity intervention promoted short-term adoption of routine walking in female students (19). In a study from Nepal, about $85 \%$ of young adults met the WHO

\begin{tabular}{|c|c|c|c|}
\hline Pre- and postintervention comparison & $\begin{array}{l}\text { Meeting WHO } \\
\text { criteria, } \mathbf{n}(\%)\end{array}$ & $\begin{array}{l}\text { Percentage } \\
\text { difference }\end{array}$ & $\begin{array}{l}\text { Difference in difference } \\
(95 \% \mathrm{CI})\end{array}$ \\
\hline \multicolumn{4}{|l|}{ Intervention group } \\
\hline $\begin{array}{l}\text { Postintervention } \\
\text { Preintervention }\end{array}$ & $\begin{array}{l}48(90.5) \\
37(69.8)\end{array}$ & $20.7 \%$ & $26.7 \%(18.1-35.3 \%)$ \\
\hline \multicolumn{4}{|l|}{ Control group } \\
\hline $\begin{array}{l}\text { Postintervention } \\
\text { Preintervention }\end{array}$ & $\begin{array}{l}38(76.0) \\
35(70.0)\end{array}$ & $-6.0 \%$ & \\
\hline
\end{tabular}

$\mathrm{CI}=$ confidence interval; $\mathrm{WHO}=$ World Health Organization. 


\begin{tabular}{|c|c|c|c|c|c|}
\hline Domains & Pre- and postintervention total activity & $\begin{array}{l}\text { Mean, } \\
\text { min }\end{array}$ & $\begin{array}{c}\text { Mean difference, } \\
\text { min }\end{array}$ & $95 \% \mathrm{CI}$ & $\boldsymbol{P}$ \\
\hline Work & $\begin{array}{c}\text { Moderate work-related PA/week } \\
\text { Preintervention } \\
\text { Postintervention }\end{array}$ & $\begin{array}{l}120.56 \\
289.24\end{array}$ & 168.67 & $68.65-298.71$ & $<0.001$ \\
\hline Travel & $\begin{array}{l}\text { Travel-related PA/week } \\
\text { Preintervention } \\
\text { Postintervention }\end{array}$ & $\begin{array}{r}66.60 \\
129.33\end{array}$ & 62.73 & $17.91-132.27$ & $<0.001$ \\
\hline \multirow[t]{2}{*}{ Recreational } & $\begin{array}{l}\text { Vigorous-recreation-related PA/ week } \\
\text { Preintervention } \\
\text { Postintervention }\end{array}$ & $\begin{array}{c}92.54 \\
124.71\end{array}$ & 32.16 & $27.1-127.2$ & 0.002 \\
\hline & $\begin{array}{c}\text { Moderate-recreation-related PA/week } \\
\text { Preintervention } \\
\text { Postintervention }\end{array}$ & $\begin{array}{l}133.11 \\
191.69\end{array}$ & 58.60 & $20.0-197.5$ & 0.006 \\
\hline Total & $\begin{array}{l}\text { Total daily PA } \\
\text { Preintervention } \\
\text { Postintervention }\end{array}$ & $\begin{array}{c}67.95 \\
115.97\end{array}$ & 48.01 & $28.0-68.1$ & $<0.001$ \\
\hline
\end{tabular}

CI = confidence interval; $P A=$ physical activity.

recommendations for physical activity (17). A communitybased cross-sectional study using GPAQ in India reported comparable findings as regards vigorous activity, with a low proportion of people engaged in vigorous activities, at work or for recreation, although walking and cycling were more common when compared with the current study (20). This difference is explained by the peculiar social circumstances in Saudi Arabia; most of the students are driven by car to the university and have to walk within the campus. Cycling is not common among men or women and has little relevance to our study population.

Similar results were reported in a recent study from the Islamic Republic of Iran that assessed the impact of digital-media-based intervention and education on physical activity in Muslim women. There was a significant increase in physical activity of women who used educational multimedia and websites and received daily text messages, compared with those in the control group, indicating a positive impact of media as educational interventions on health promotion (21). In our study, we noted that after intervention, there was a significant difference in the MET minutes per week within the intervention group and between the intervention and control groups. These findings are similar to previous reports (21).

The preintervention analysis showed that $\sim 70 \%$ from both groups met the minimum WHO criteria, which improved to $90 \%$ in the intervention group but remained the same in the control group after intervention. The baseline levels of physical activity by WHO criteria were similar in other studies. In a multinational European population study, $87 \%$ of participants met the criteria (22), and $72 \%$ of young adult women met the criteria in a study in Nepal (17).

This study did not find any significant association between marital status and physical activity. Several recent studies have indicated that being single, divorced or widowed carries a risk of adverse health outcomes, which suggests that the presence of a spouse is key for helping individuals adopt a more active lifestyle $(22,23)$. A prospective study in Japan reported that adherence to walking exercise was twice as high in couples as in noncouples (24). In another study, higher physical activity

Table 5 Pre- and postintervention change in total MET per week in the intervention group

\begin{tabular}{|c|c|c|c|c|c|}
\hline Domain of PA & $\begin{array}{c}\text { Preintervention mean, } \\
\text { MET/min }\end{array}$ & $\begin{array}{c}\text { Postintervention mean, } \\
\text { MET/min }\end{array}$ & $\begin{array}{c}\text { Mean } \\
\text { difference } \\
\text { MET/min }\end{array}$ & $95 \% \mathrm{CI}$ & $P$ \\
\hline \multicolumn{6}{|l|}{ Work } \\
\hline Vigorous & $438.1(113.4)$ & $325.4(102.4)$ & 112.62 & $115.8-341.1$ & 0.334 \\
\hline Moderate & $527.2(77.2)$ & $838.8(129.2)$ & 311.65 & $93.31-529.9$ & 0.006 \\
\hline \multicolumn{6}{|l|}{ Travel } \\
\hline Walking/cycle & $255.9(57.2)$ & $388.2(69.7)$ & 132.23 & $36.6-227.8$ & 0.007 \\
\hline \multicolumn{6}{|l|}{ Recreation } \\
\hline Vigorous & $685.1(101.1)$ & $870.6(118.1)$ & 185.63 & $29.1-400.4$ & 0.089 \\
\hline Moderate & $529.7(68.4)$ & $638.6(74.1)$ & 108.93 & $0.41-218.3$ & 0.049 \\
\hline Total PA in MET/min & $2435.9(219.2)$ & $3061.7(312.1)$ & 625.8 & $169.2-1082.4$ & 0.008 \\
\hline
\end{tabular}

$\mathrm{CI}=$ confidence interval; $M E T=$ metabolic equivalents; $P A=$ physical activity. 
was reported among married pairs than among formerly married singles (25). The lack of such an association in the current study may be explained by the choice of sample, in which only a small proportion was married. Significant improvement in physical activity was noted in older participants and those with a higher level of education.

The current study had some limitations. Although the effect of the intervention was large enough to detect significant differences between our study groups, the results cannot be generalized because of the small sample size and the study was conducted in only 1 city. All of the information was self-reported which increased the potential recall bias. However, the study had some strengths. This was a randomized controlled trial with comparable participants in both the intervention and control groups and successfully demonstrated the effectiveness of the intervention.

\section{Conclusion}

This study is a pioneering work on the successful implementation of social media for promoting physical activity among young women in Aseer Region. The results are encouraging and reveal increased levels of activity in the intervention group in all domains of physical activity. This indicates that technological advancements can be effectively used as a tool for health promotion. It is recommended that multicentre, longer follow-up studies with larger samples should be conducted. This would enable sustained improvement in physical activity and help inform policy for positive health behaviour change in this population group.

Funding: None.

Competing interests: None declared.

\section{Intervention basée sur WhatsApp pour la promotion de l'activité physique chez les étudiantes des universités d'Arabie saoudite : un essai contrôlé randomisé}

\section{Résumé}

Contexte: Les jeunes adultes du monde entier utilisent de plus en plus les médias sociaux. La question est de savoir si ces réseaux peuvent être intégrés avec succès dans les programmes de santé visant à promouvoir l'activité physique.

Objectifs : La présente étude vise à mesurer l'effet d'une intervention basée sur WhatsApp pour la promotion de l'activité physique chez les étudiantes des universités à Abha, en Arabie saoudite.

Méthodes : Le présent essai contrôlé randomisé, réalisé de novembre 2019 à janvier 2020, a inclus 110 étudiantes. Le groupe d'intervention a reçu une brève orientation sur l'exercice et quatre messages de promotion sur l'activité physique par semaine via WhatsApp pendant 10 semaines. Les messages ont été obtenus à partir des sites Web des Centers for Disease Control américains et de l'Organisation mondiale de la Santé (OMS). L'activité physique a été évaluée au départ et après 10 semaines de suivi à l'aide du questionnaire mondiale sur la pratique d'activités physiques de l'OMS.

Résultats : Les deux groupes étaient similaires en matière de caractéristiques socio-démographiques et de niveaux d'activité physique de départ. L'analyse des données post-intervention a révélé une amélioration significative dans la proportion de participants ayant une activité physique d'intensité modérée dans les domaines du travail et des loisirs. Par rapport au groupe témoin, les équivalents métaboliques moyens/semaine du groupe d'intervention se sont améliorés de manière importante. La différence moyenne d'activité physique totale avant et après l'intervention était significative dans tous les domaines et dans toutes les catégories d'activité. La proportion de participants qui répondaient aux critères de l'OMS pour une activité physique minimale par semaine est passée de $69,8 \%$ à $90,5 \%$ après l'intervention.

Conclusion : Les interventions basées sur les réseaux sociaux améliorent l'activité physique et peuvent être intégrées dans des programmes de santé ciblant les jeunes.

$$
\begin{aligned}
& \text { التدخل القائم على تطبيق الواتساب لتعزيز الثشاط البدني بين الطالبات الجامعيات في المملكة العربية السعودية: تجربة } \\
& \text { عشو ائية مضبوطة الفائ علئ } \\
& \text { أمل الشهراني، عائشة صديقي، شمسون خليل، شحاتة فرج، نجم الشهراني، عبد الله السبعاني، حسن قريري } \\
& \text { الخلاصة } \\
& \text { الخلفية: يتزايد استخدام صغار الشباب في جميع أنحاء العالم لوسائل التو اصل الاجتماعي. و المسألة قيد البحث هي ما إذا كان يمكن دجبها بنجاح في } \\
& \text { البرامج الصحية لتعزيز النشاط البدني. }
\end{aligned}
$$


الأهداف: هدفت هذه الدراسة المى قياس تأثير التدخل القائم على تطبيق الواتساب لتعزيز النشاط البدني بين الطالبات الجامعيات في مدينة أبها، المملكة العربية السعودية.

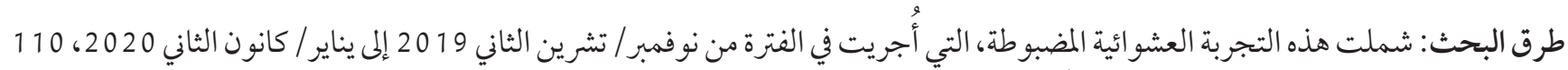

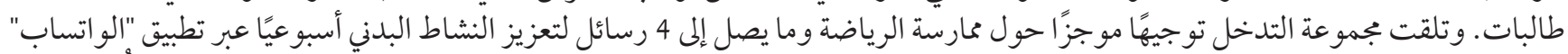

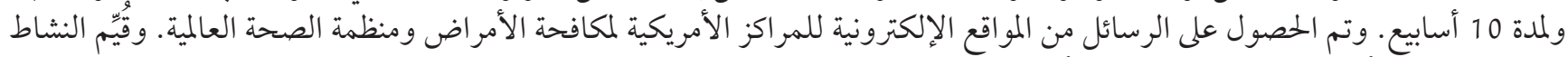

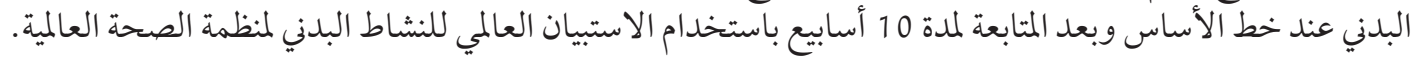

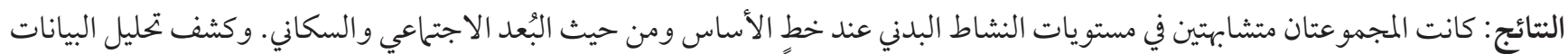

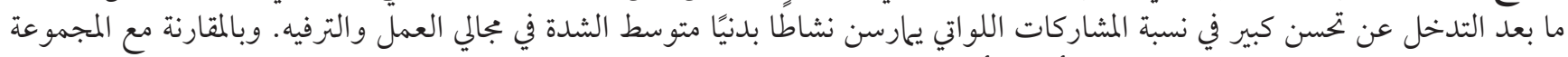

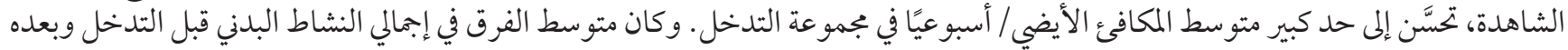

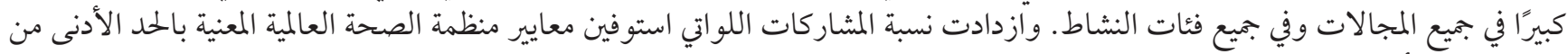

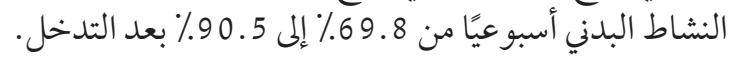

الاستنتاج: تؤدي التدخلات القائمة على الشبكات الاجتماعية إلى تحسين النشاط البدني، ويمكن دبجها في البرامج الصحية التي تستهدف الشباب.

\section{References}

1. Global action plan on physical activity 2018-2030: more active people for a healthier world: at-a-glance (No. WHO/NMH/ PND/18.5). Geneva: World Health Organization; 2018 (https://www.who.int/ncds/prevention/physical-activity/global-action-plan-2018-2030/en/, accessed 16 February 2021).

2. Physical activity fact sheet [website]. Geneva: World Health Organization; 2015 (https://www.who.int/news-room/fact-sheets/ detail/physical-activity, accessed 16 February 2021).

3. Lee I-M, Shiroma EJ, Lobelo F, Puska P, Blair SN, Katzmarzyk PT et al. Effect of physical inactivity on major non-communicable diseases worldwide: an analysis of burden of disease and life expectancy. Lancet. 2012 Jul 21;380(9838):219-29. https://doi. org/10.1016/So140-6736(12)61031-9 PMID:22818936

4. Global recommendations on physical activity for health [website]. Geneva: World Health Organization; 2010 (https://www.who. int/publications/i/item/9789241599979, accessed 16 February 2021).

5. Al-Hazzaa HM. Physical inactivity in Saudi Arabia revisited: a systematic review of inactivity prevalence and perceived barriers to active living. Int J Health Sci. 2018 NovDec;12(6):50-64. PMID:30534044

6. Miller T, Chandler L, Mouttapa M. A needs assessment, development, and formative evaluation of a health promotion smartphone application for college students. Am J Health Educ. 2015;46(4):207-15. https://doi.org/10.1080/19325037.2015.1044138

7. Alssafi AH. (2018). A Mobile-based intervention for obesity prevention among female college students in Saudi Arabia: a randomized controlled trial. FIU Electronic Theses Dissertations. 3877. https://digitalcommons.fiu.edu/etd/3877

8. Fukuoka Y, Vittinghoff E, Jong SS, Haskell W. Innovation to motivation-pilot study of a mobile phone intervention to increase physical activity among sedentary women. Prev. Med. 2010 Sep-Oct 51(3-4):287-9. https://doi.org/10.1016/j.ypmed.2010.06.006 PMID:20600263

9. Richards J, Thorogood M, Hillsdon M, Foster C. (2013). Face-to-face versus remote and web 2.0 interventions for promoting physical activity. Cochrane Database Syst Rev. 2013 Sep 30;(9):CDo10393. https://doi.org/10.1002/14651858.CDo10393.pub2

10. WhatsApp: usage penetration in selected countries [website]. New York: Statista (https://www.statista.com/statistics/291540/ mobile-internet-user-whatsapp, accessed 16 February 2021).

11. Kamel Boulos MN, Giustini DM, Wheeler S. Instagram and WhatsApp in health and healthcare: an overview. Future Internet. 2016;8(3):37. https://doi.org/10.3390/fi8030037

12. Armstrong T, Bull F. Development of the world health organization global physical activity questionnaire (GPAQ). J Public Health. 2006;14(2):66-70. https://doi.org/10.1007/s10389-006-0024-x

13. Al-Eisa E, Al-Rushud A, Alghadir A, Anwer S, Al-Harbi B, Al-Sughaier N et al.. Effect of motivation by "Instagram" on adherence to physical activity among female college students. BioMed Res Int. 2016; Article ID 1546013. https://doi.org/10.1155/2016/1546013

14. Global Physical Activity Questionnaire (GPAQ). Geneva: World Health Organization (http://www.who.int/ncds/surveillance/ steps/resources/GPAQ_Analysis_Guide.pdf).

15. Doyle CB, Khan A, Burton NW. Recreational physical activity context and type preferences among male and female Emirati university students. Int Health. 2019 Nov;11(6):507-12. https://doi.org/10.1093/inthealth/ihzoo2

16. Thapa K, Bhandari PM, Neupane D, Bhochhibhoya S, Rajbhandari-Thapa J, Prasad Pathak R. Physical activity and its correlates among higher secondary school students in an urban district of Nepal. BMC Public Health. 2019 Jul 5;19(1):886. https://doi. org/10.1186/s12889-019-7230-2 PMID:31277633 
17. Lindgren T, Hooper J, Fukuoka Y. Perceptions and experiences of women participating in a digital technology-based physical activity intervention (the mPED Trial): qualitative study. JMIR Public Health Surveill. 2019 Dec 20;5(4):e13570. https://doi. org/10.2196/13570 PMID:31859677

18. Ornes L, Ransdell LB. Web-based physical activity intervention for college-aged women. Int Electronic J Health Educ. 2007;10:126-37.

19. Kumari R, Bansal D, Nath B. Pattern of physical activity and associated sociodemographic factors: a community based study using Global Physical Activity questionnaire. Ceylon Med J. 2018 Dec 31;63(4):159-68. https://doi.org/10.4038/cmj.v63i4.8774 PMID:30669210

20. Peyman N, Rezai-Rad M, Tehrani H, Gholian-Aval M, Vahedian-Shahroodi M, Heidarian Miri H. Digital media-based health intervention on the promotion of women's physical activity: a quasi-experimental study. BMC Public Health. 2018 Jan 15;18(1):134. https://doi.org/10.1186/s12889-018-5025-5 PMID:29334970

21. Ikeda A, Iso H, Toyoshima H, Fujino Y, Mizoue T, Yoshimura T et al. Marital status and mortality among Japanese men and women: the Japan Collaborative Cohort Study. BMC Public Health 2007;7(1):73. https://doi.org/10.1186/1471-2458-7-73

22. Manzoli L, Villari P, Pirone GM, Boccia A. Marital status and mortality in the elderly: a systematic review and meta-analysis. Soc Sci med. 2007 Jan;64(1):77-94. https://doi.org/10.1016/j.socscimed.2006.08.031 PMID:17011690

23. Robards J, Evandrou M, Falkingham J, Vlachantoni A. Marital status, health and mortality. Maturitas. 2012 Dec;73(4):295-9. https://doi.org/10.1016/j.maturitas.2012.08.007 PMID:23007006

24. Osuka Y, Jung S, Kim T, Okubo Y, Kim E, Tanaka K. Does attending an exercise class with a spouse improve long-term exercise adherence among people aged 65 years and older: a 6-month prospective follow-up study. BMC Geriatrics. 2017 Jul 31;17(1):170. https://doi.org/10.1186/s12877-017-0554-9 PMID:28760148

25. Gellert P, Ziegelmann JP, Warner LM, Schwarzer R. Physical activity intervention in older adults: does a participating partner make a difference? Eur J Ageing. 2011 Jul 7;8(3), 211. https://doi.org/10.1007/s10433-011-0193-5 PMID:28798651 